\title{
PERFORMANSI PERTUMBUHAN DAN REPRODUKSI UDANG WINDU, Penaeus monodon YANG DIBERI PAKAN DENGAN PENAMBAHAN VITAMIN C DAN E
}

\author{
Usman\#, Kamaruddin, Asda Laining, Samuel Lante, dan Bunga Rante Tampangallo \\ Balai Riset Perikanan Budidaya Air Payau dan Penyuluhan Perikanan \\ Jl. Makmur Dg. Sitakka No. 129, Maros 90511, Sulawesi Selatan \\ (Naskah diterima: 5 Agustus 2019; Revisi final: 28 Oktober 2019; Disetujui publikasi: 30 Oktober 2019)
}

\begin{abstract}
ABSTRAK
Penelitian ini bertujuan mengevaluasi pengaruh penambahan vitamin $C$ dan $E$ dalam pakan terhadap performansi pertumbuhan dan reproduksi udang windu fase prematurasi. Dua pakan uji dengan perlakuan: penambahan vitamin C (mengandung ascorbic acid 406,1 mg/kg) dan vitamin E (mengandung 286,3 mg/kg) (PS), dan tanpa penambahan vitamin $C$ dan $E(P K)$. Hewan uji yang digunakan adalah udang windu fase prematurasi hasil budidaya berbobot awal $43,1 \pm 5,1 \mathrm{~g}$ untuk betina dan $41,9 \pm 4,4 \mathrm{~g}$ untuk jantan, dipelihara dalam 2 petak tambak beton berukuran $1000 \mathrm{~m}^{2}$ dengan kepadatan awal 100 ekor/tambak dan rasio udang jantan : betina adalah $4: 6$. Udang tersebut diberi pakan uji sebanyak $3 \%$ dari biomassa per hari selama 3 bulan di tambak. Selanjutnya udang dipindahkan ke bak pematangan gonad untuk mengevaluasi kinerja reproduksinya. Hasil penelitian menunjukan bahwa,laju pertumbuhan spesifik, total hemosit, jumlah sel sperma, gonada somatic indeks, dan hepatosomatic indeks cenderung lebih tinggi pada udang yang diberi pakan uji PS dibandingkan yang diberi pakan PK. Udang yang diberi pakan uji PS juga memiliki fekunditas, diameter telur, daya tetas telur, dan produksi nauplii yang cenderung lebih tinggi, meskipun secara statistik tidak berbeda nyata $(P>0,05)$ di antara kedua perlakuan. Hasil penelitian ini menunjukkan penambahan vitamin $\mathrm{C}$ dan $\mathrm{E}$ dalam pakan cenderung meningkatkan performansi pertumbuhan dan reproduksi udang windu.
\end{abstract}

\section{KATA KUNCl: udang windu, pertumbuhan, reproduksi,vitamin C dan E}

ABSTRACT: Growth and reproductive performances of tiger shrimp, Penaeus monodon, fed vitamin C and E supplemented diet. By: Usman, Kamaruddin, Asda Laining, Samuel Lante, and Bunga Rante Tampangallo

\begin{abstract}
This experiment was aimed to evaluate the effects of feed supplemented with vitamin $C$ and $E$ on the growth and reproductive performances of prematurated tiger shrimp. Two test diets were formulated as the treatments: diet with the addition of vitamin C (contain ascorbic acid of $406.1 \mathrm{mg} / \mathrm{kg}$ diet) and vitamin E (contain $286.3 \mathrm{mg} / \mathrm{kg}$ diet) (PS), and a diet without the addition of vitamin $C$ and $E$ (PK). The test shrimp were prematurated tiger shrimp with an average initial weight of $43.1 \pm 5.1 \mathrm{~g} / \mathrm{ind}$. for females and $41.9 \pm 4.4 \mathrm{~g} / \mathrm{ind}$. for males. The tiger shrimp were cultured in two of $1,000 \mathrm{~m}^{2}$ concrete ponds with a density of 100 ind./pond, and the ratio of male : female was $4: 6$. The shrimp were fed with the experimental diets at a rate of $3 \%$ of body weight/day for three months. The shrimp were then transferred to concretetanks for reproductive evaluation. The results showed that the specific growth rates, total hemocytes, number of sperm cells, gonado-somatic index, and hepatosomatic index tended to behigher in the shrimp fed with the PS test diet compared to the shrimp fed with the PK test diet. The shrimp fed with the PS test diet had higher egg fecundity, egg diameter, hatching rate, and nauplii production compared to the shrimp fed with the PK test diet. However, the study found no significant difference $(P>0.05)$ between the two treatments. The addition of vitamins $C$ and $\mathrm{E}$ in the diet could improve the growth and reproductive performance of tiger shrimp.
\end{abstract}

\section{KEYWORDS: $\quad$ tiger shrimp; growth; reproduction; vitamin C and E}

\footnotetext{
\# Korespondensi: Balai Riset Perikanan Budidaya Air Payau dan

Penyuluhan Perikanan. Jl. Makmur Dg. Sitakka No. 129,

Maros 90511, Sulawesi Selatan, Indonesia.

Tel. + 62411371544

E-mail: siganus007@yahoo.com
} 


\section{PENDAHULUAN}

Domestikasi udang windu harus terus dilakukan agar dihasilkan induk yang berkualitas melalui kegiatan budidaya yang ramah lingkungan dan berkelanjutan. Untuk menghasilkan induk yang berkualitas, maka pengembangan pakan buatan dengan spesifikasi nutrisi tertentu harus dilakukan sejak fase prematurasi yaitu saat ukuran udang sekitar $40 \mathrm{~g}$ karena pada fase tersebut udang windu sudah memasuki fase persiapan untuk perkembangan organ reproduksi (Paibulkichakul et al., 2008; Hoa, 2009). Beberapa hasil penelitian melaporkan tentang kebutuhan nutrien udang windu pada masa awal fase reproduksi tersebut seperti: dosis dan jenis karotenoid yaitu astaxanthine $(0,125 \%$; cantaxanthine $(0,068 \%)$; dan karotenoid dari spirulina $(0,3 \%$ ditemukan berperan penting dalam peningkatan jumlah induk matang gonad sebesar $86,75 \%$ pada udang betina dan sebesar 82,3\%pada udang jantan (Laining et al., 2016a). Kadar total karotenoid tersebut juga meningkat dalam oosit dan hepatopankreas masingmasing sebesar 554,6 dan 558,1 $\mu \mathrm{g} / \mathrm{g}$ lebih tinggi dibandingkan dalam daging dan karkas yang berturutturut hanya sebesar 249,3 dan 55,8 $\mu \mathrm{g} / \mathrm{g}$. Pengkayaan pakan komersil dengan kombinasi lemak (minyak ikan $5 \%$ dan minyak zaitun $1 \%$ juga dilaporkan cenderung meningkatkan pertumbuhan dan meningkatkan total asam lemak dalam daging dan hepato pankreas udang windu dibandingkan pakan komersil tanpa pengayaan lemak tersebut (Laining et al., 2016b).

Nutrien lainnya yang dilaporkan juga sangat diperlukan dalam masa pertumbuhan dan reproduksi ikan dan krustase adalah vitamin C dan E. Vitamin ini tidak dapat disintesis di dalam tubuh sehingga harus diperoleh melalui asupan makanan. Penelitian pada udang kuruma (Marsupenaeus japonicus) menunjukkan bahwa vitamin C maupun vitamin E meningkatkan daya tetas dan tingkat metamorfosis larva dari naupli ke zoea seiring dengan meningkatnya dosis kedua vitamin tersebut yaitu 0,500 , dan $1.000 \mathrm{mg}$ ascorbic acid/ $\mathrm{kg}$ pakan dan 0,300, dan $600 \mathrm{mg} \alpha$-tocopherol $/ \mathrm{kg}$ pakan, dan interaksi antara vitamin C dan E dideteksi pada kedua variabel tersebut (Binh et al., 2012). Selanjutnya, pada fase maturasi udang galah (Macrobrachium rosenbergii) dilaporkan bahwa suplementasi vitamin C hingga $918 \mu \mathrm{g} / \mathrm{g}$ dan vitamin E hingga $899 \mu \mathrm{g} / \mathrm{g}$ meningkatkan konsentrasi asam askorbat dan $\alpha$-tocopherol dalam oosit dan larva seiring dengan meningkatnya kadar kedua vitamin tersebut dalam pakan, namun tidak berpengaruh nyata padafrekuensi pemijahan dan fekunditas udang (Cavalli et al., 2003). Paibulkichakul et al. (2008) menggunakan vitamin E sebanyak $100 \mathrm{mg} / \mathrm{kg}$ pakan untuk udang windu fase prematurasi. Demikian juga Laining et al. (2014) menggunakan konsentrasi vitamin C sebanyak
$200 \mathrm{mg} / \mathrm{kg}$ dan konsentrasi vitamin E sebanyak 100 $\mathrm{mg} / \mathrm{kg}$ dalam pakan induk udang windu. Sementara Alava et al. (1993) menerapkan konsentrasi asam askorbat (vitamin C) $492 \mathrm{mg} / \mathrm{kg}$ dan vitamin E 482 $\mathrm{mg} / \mathrm{kg}$ dalam pakan untuk memacu perkembangan ovarium udang kuruma, Penaeus javonicus. Meskipun penting dalam proses reproduksi, vitamin E yang berlebihan dalam pakan juga dapat mengganggu proses metabolisme seperti timbulnya reaksi toksik dalam hati dan memperlambat pertumbuhan ikan (Halver, 2002).

Selain faktor tersebut, vitamin $\mathrm{C}$ dan vitamin $\mathrm{E}$ juga berperan penting dalam menstimulasi mekanisme imun pada hewan akuatik, serta berfungsi sebagai antioksidan yang kuat (Guillaume et al., 1999). Kondisi lingkungan hidup udang yang sering tidak mendukung dan serangan penyakit yang semakin meningkat saat ini cenderung menyebabkan udang mengalami stres tinggi yang tentunya memicu terjadinya radikal bebas, sehingga sangat diperlukan adanya respons imun yang tinggi, serta peran dari antioksidan ini. Berdasarkan hal tersebut, maka penelitian ini dilakukan untuk mendapatkan informasi tentang pengaruh penambahan vitamin $C$ dan vitamin $\mathrm{E}$ dalam pakan terhadap performansi pertumbuhan dan reproduksi udang windu fase prematurasi dalam rangka mendukung domestikasi.

\section{BAHAN DAN METODE}

\section{Pakan Uji}

Bahan utama untuk pakan uji berupa pakan udang komersial yang memiliki kandungan protein sekitar $45 \%$ dan lemak sekitar $6 \%$ berbentuk crumble (starter), dan ditepungkan. Penambahan bahan lainnya berupa tepung ikan, tepung terigu dan wheat gluten untuk menghasilkan pakan dengan kandungan protein sekitar $45 \%$ lemak $11 \%$ dan gross energy $18,3 \mathrm{MJ} / \mathrm{kg}$; serta ketahanan dalam air $\geq 4$ jam. Berdasarkan hasil penelitian sebelumnya, juga dilakukan penambahan karotenoid (Laining et al., 2016a) dan penambahan sumber lemak (Laining et al., 2016b). Sebagai perlakuan adalah penambahan vitamin $C$ dan vitamin E dalam pakan yaitu: PS = dalam formulasi pakan ditambahkan $0,2 \%$ Stay $\mathrm{C}$ (mengandung ascorbic acid $36 \%$ dan vitamin $\mathrm{E}$ sebanyak $0,02 \%$ (mengandung $50 \%$ tocoferol), sehingga dalam pakan mengandung ascorbic acid 406,1 mg/kg pakan dan tocoferol 286,3 mg/kg pakan; dan PK = dalam formulasi pakan tanpa penambahan vitamin $C$ dan vitamin E. Komposisi bahan dan proksimat pakan uji disajikan pada Tabel 1. Komposisi pakan ini juga digunakan untuk mengetahui pengaruh vitamin $\mathrm{C}$ dan $\mathrm{E}$ terhadap profil asam lemak pada hepatopancreas dan oosit dari udang windu (Usman et al., 2019). 
Tabel 1. Komposisi bahan dan komposisi proksimat pakan uji (\%bahan kering)

Table 1. Ingredients and proximate composition of test diets (\%dry matter)

\begin{tabular}{lcc}
\hline \multicolumn{1}{c}{ Bahan (Ingredients) } & PS & PK \\
\hline Pakan udang komersial & 67.4 & 67.4 \\
Commercial shrimp-feed & 14.2 & 14.2 \\
Tepung ikan (Fish meal) & 9.32 & 9.54 \\
Tepung terigu (Wheat flour) & 4.8 & 4.8 \\
Wheat gluten & 3 & 3 \\
Minyak ikan (Fish oil) & 1 & 1 \\
Minyak olive (Olive oil) & 0.2 & 0 \\
Vitamin C (Stay C) & 0.02 & 0 \\
Vitamin E & 0.06 & 0.06 \\
Carophyll pink & & \\
\hline Komposisi proksimat pakan (Proximate composition of test diets): & 45.2 & 44.9 \\
- Protein kasar (Crude protein) & 10.7 & 10.5 \\
- Lemak (Lipid) & 1.7 & 1.7 \\
- Serat kasar (Crude fibre) & 9.6 & 9.7 \\
- Abu (Ash) & 32.8 & 33.2 \\
- BETN (NFE) & 18.3 & 18.3 \\
- Energi total (Gross energy) (MJ/kg) ${ }^{2)}$ & & Tidak terdeteksi \\
- Vitamin C (mg/kg) & 406.1 & Not detected \\
- Vitamin E (mg/kg) & 286.3 & 181.6 \\
\hline
\end{tabular}

\section{Pemeliharaan Hewan Uji dan Pengumpulan Data}

\section{Pemeliharaan udang di tambak beton}

Udang windu hasil seleksi ditebar dan dipelihara pada dua petak tambak masing-masing berukuran $1.000 \mathrm{~m}^{2}$ per petak. Hewan uji berupa udang windu fase prematurasi dengan bobot awal rata-rata $43,1 \pm$ $5,1 \mathrm{~g}$ untuk betina dan $41,9 \pm 4,4 \mathrm{~g}$ untuk jantan diperoleh dari hasil budidaya. Udang tersebut ditebar dengan kepadatan 100 ekor per tambak $\left(0,1\right.$ ekor $\left./ \mathrm{m}^{2}\right)$ dengan rasio jantan : betina masing-masing 4:6. Pemberian pakan uji dilakukan empat kali sehari pada pagi, siang, sore, dan malam hari dengan dosis 3\% dari bobot biomassa per hari selama tiga bulan masa pemeliharaan.

Pengamatan pertumbuhan udang dilakukan setiap bulan. Setelah pemeliharaan selama dua bulan dan tiga bulan (saat panen) udang di tambak, dilakukan pengambilan cairan haemolimp untuk analisis jumlah total sel hemosit dan aktivitas phenoloksidase dalam tubuh sebagai indikator respons imun udang berdasarkan metode yang dilakukan oleh Tenriulo et al. (2014). Untuk mempertahankan mutu air tetap dalam kondisi optimal, maka dilakukan pergantian air setiap tiga hari sebanyak 10\%20\% serta penggunaan kincir pada malam hari. Selama pemeliharaan, dilakukan pengukuran beberapa peubah kualitas air secara harian dan mingguan seperti salinitas (27-36 ppt), suhu air $\left(26,14^{\circ} \mathrm{C}-32,12^{\circ} \mathrm{C}\right)$; $\mathrm{pH}(8,29-8,50)$; amoniak nitrogen total (TAN: 0,0600-0,3637 mg/L); nitrit (0,0056-0,0077 mg/L); dan alkalinitas ( $90-116 \mathrm{mg} /$ L). Nilai kualitas air tersebut cukup optimum untuk pertumbuhan dan kehidupan udang windu.

\section{Pemeliharaan udang di bak pematangan gonad}

Setelah tiga bulan pemeliharaan di tambak, udang sudah mencapai fase akhir prematurasi (calon induk) dengan ukuran bobot $>80 \mathrm{~g}$ untuk betina dan $>70$ $g$ untuk jantan. Udang tersebut dipanen dan dipindahkkan ke bak maturasi (bak beton) untuk dimatangkan gonadnya di hatchery. Proses pematangan gonad induk udang ini terdiri atas dua bagian:

(i) Induk dimatangkan gonadnya untuk diambil sampel gonad dan hatinya untuk menghitung gonad somatic index (GSI), hepato somatic index (HSI), dan jumlah sperma dalam spematofora

(ii) Induk dimatangkan gonadnya untuk dipijahkan, ditetaskan telurnya, dan menghasilkan nauplii (larva) 
Pada bagian (i), induk udang dipelihara dalam dua bak beton masing-masing berkapasitas $20 \mathrm{~m}^{3}$. Induk yang terseleksi untuk dimatangkan gonadnya masingmasing 40 ekor untuk perlakuan PS dan 40 ekor untuk perlakuan PK (masing-masing 20 ekor betina dan 20 ekor jantan). Pada proses maturasi, udang diberi pakan sebanyak 3\%dari total biomassa per hari berupa pakan uji $50 \%$ (pelet) dan pakan segar $50 \%$ (cumi-cumi dan hati sapi). Induk yang telah memiliki tingkat kematangan gonad (TKG) III-IV (berdasarkan kriteria oleh Diwan et al., 2009) dibedah, diambil dan ditimbang gonad dan hepatopankreasnya untuk udang betina. Sementara pada induk jantan, spermatofora dari induk dikeluarkan mengikuti metode yang digunakan Lante \& Laining (2016) dengan menggunakan transformer elektrik yang dilengkapi dua elektroda. Kedua el ektroda ditempelkan dekat kaki renang ke-5 dengan rangsangan aliran listrik 4-20 volt $A C$ sehingga spematofora keluar. Spermatofora ditimbang, dimasukkan ke dalam tabung dan ditambahkan 3,0 mL larutan $\mathrm{Ca}_{2}{ }^{+}$bebas garam, serta dihomogenkan dengan homogenizer. Spermatozoa diambil sebanyak $0,1 \mathrm{~mL}$ dan dimasukkan ke dalam hematocitometer untuk dihitung di bawah mikroskop.

Pada bagian (ii), induk udang dipelihara dalam empat bak beton masing-masing berkapasitas $3 \mathrm{~m}^{3}$. Bak dilengkapi dengan sistem air mengalir. Setiap perlakuan pakan uji (PS dan PK) masing-masing terdiri dari dua unit bak (ulangan). Induk udang dipelihara dengan kepadatan 14 ekor per bak dengan perbandingan tujuh ekor induk betina dan tujuh ekor induk jantan. Setiap individu udang diberi penanda (tagging) pada bagian tangkai mata dan karapaks udang. Induk betina yang telah ganti kulit lalu diinseminasi (mengikuti metode yang digunakan Lante $\&$ Laining, 2016) dengan spermatofora dari jantannya, Ialu diablasi, dan selanjutnya diamati perkembangan gonad hingga pemijahannya selama 40 hari pemeliharaan di bak beton. Pengamatan harian perkembangan kematangan gonad dilakukan setelah tujuh hari ablasi setiap pukul 16.30-17.00 WITA. Induk matang (TKGIII-IV) dipindahkan ke bak pemijahan volume $200 \mathrm{~L}$. Jumlah induk yang memijah dihitung, dan selanjutnya dikembalikan ke bak pematangan. Telur yang dipijahkan diambil sampelnya yang representatif untuk dihitung jumlahnya. Penetasan telur dilakukan dalam bak pemijahan setelah dilakukan pembersihan dan pensucihamaan telur dengan iodin. Telur yang menetas menjadi nauplii diambil sampelnya yang representatif dan dihitung untuk mengetahui daya tetas telur dan jumlah produksi nauplii.

\section{Peubah yang diamati}

Dalam mengevaluasi efek dari pemberian pakan uji, maka dilakukan pengamatan terhadap beberapa peubah yaitu:

- Laju pertumbuhan spesifik udang dihitung berdasarkan rumus berikut (Xavier et al., 2016):

$$
\text { SGR }(\% \text { hari })=\frac{(\text { LnWt }- \text { LnWo })}{t} \times 100 \%
$$

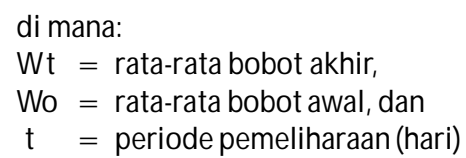

- Sintasan

$$
\text { SR }\left(\%=\frac{\text { Jumlah udang akhir penelitian }}{\text { Jumlah udang awal penelitian }} \times 100\right.
$$

- Pengamatan jumlah sperma dilakukan berdasarkan metode yang digunakan oleh Laining et al. (2014).

- Gonadsomaticindex $=\frac{\text { bobot gonad }}{\text { bobot total tubuhudang }} \times 100 \%$

- Hepatosomaticindex $=\frac{\text { bobot hepatopankeas }}{\text { bobot total tubuhudang }} \times 100 \%$

- Tingkat pemijahan merupakan persentase jumlah pemijahan induk betina dari jumlah induk yang diinseminasi.

- Fekunditas telur yaitu jumlah telur yang dihasilkan oleh seekor induk pada setiap pemijahan (Yano et al., 1996), yang dihitung dengan rumus:

$$
F=(V b: V g) \times n
$$

di mana:

$\mathrm{F}=$ fekunditas telur (butir telur)

$\mathrm{Vb}=$ volume air di dalam bak pemijahan (L)

$\mathrm{Vg}=$ volume air sampel dalam beaker glass $(\mathrm{mL})$

$\mathrm{n}=$ jumlah telur sampel yang ada di dalam beaker glass (butir)

- Daya tetas telur dihitung berdasarkan persentase jumlah telur yang menetas menjadi nauplii terhadap jumlah produksi telur

- Diameter telur, total produksi telur, dan total produksi nauplii per bak

Pada analisis proksimat pakan uji, sampel yang representative dianalisis berdasarkan AOAC (1999) berupa: bahan kering (DM), contoh dikeringkan dengan oven 
pada suhu $105^{\circ} \mathrm{C}$ hingga bobotnya konstan, protein kasar dianalisis dengan metode micro-Kjeldahl, dan lemak ditentukan secara gravimetrik dengan ekstraksi chloroform: methanol pada sampel, serat kasar dengan pemanasan yang disert(dabpekguxirian asam dan basa secara bergantian, dan abu dengan pembakaran dalam tanur pada suhu $550^{\circ} \mathrm{C}$ selama 24 jam. Kandungan vitamin C dan E dalam pakan dianalisis di Laboratorium Saraswanti, Bogor menggunakan high performanceliquid chromatography (HPLC).

Peubah performansi pertumbuhan (sintasan dan laju pertumbuhan), respons imun (jumlah total hemosit dan aktivitas phenoloksidase) pada pemeliharaan di tambak, serta beberapa peubah reproduksi seperti jumlah sperma, GSI, dan HIS dianalisis secara deskriptif. Sedangkan tingkat pemijahan induk, fekunditas telur, diameter telur, dan jumlah produksi telur, serta jumlah produksi nauplii dianalisis dengan uji T.

\section{HASIL DAN BAHASAN}

\section{Performansi Pertumbuhan dan Respons Imun Udang Windu di Tambak Beton}

Performansi pertumbuhan dan respons imun udang windu selama pemeliharaan di tambak beton disajikan pada Tabel 2. Pada Tabel 2 terlihat bahwa nilai laju pertumbuhan spesifik udang untuk kedua perlakuan cukup tinggi (1,09\%1,12\%hari untuk betina, dan 0,77\% $0,88 \%$ hari untuk jantan), meskipun hewan uji yang digunakan sudah memasuki fase prematurasi. Laju pertumbuhan spesifik udang windu yang diberi pakan uji dengan penambahan vitamin $\mathrm{C}$ dan vitamin $\mathrm{E}$ cenderung lebih tinggi dibandingkan udang windu yang diberi pakan uji tanpa penambahan vitamin $\mathrm{C}$ dan vitamin $\mathrm{E}$, baik udang windu betina maupun udang windu jantan. Hal ini menunjukkan bahwa penambahan vitamin $\mathrm{C}$ dan vitamin $\mathrm{E}$ dalam pakan tersebut memberikan respons positif terhadap pertumbuhan udang windu fase prematurasi di tambak. Vitamin C merupakan salah satu jenis vitamin esensial bagi ikan dan krustase yang berperan penting dalam reaksi di dalam sel, terkait dengan kemampuannya dalam proses oksidasi, dan reduksi yang reversible (Conklin, 1997), terlibat dalam pertumbuhan, biosintesis hormon steroid dan kolagen, meningkatkan respons imum dan toleransi terhadap racun dan stressor lingkungan (Waagbo, 2010; NRC, 2011). Penambahan vitamin C dalam pakan telah dilaporkan dapat meningkatkan pertumbuhan, sintasan, efisiensi pakan, laju moulting, respons imun, dan toleransi terhadap stres lingkungan pada udang penaeid (Hsu \& Shiau, 1997; Lee \& Shiau, 2002; Celada et al., 2013). Demikian juga vitamin E memiliki sifat reduksi yang tinggi yang dapat melindungi zat penting dari oksidasi secara in vivo dan berperan penting dalam pemeliharaan proses

Tabel 2. Performansi pertumbuhandan respons imun udang windu setelah pemeliharan selama tiga bulan di tambak beton

Table 2. Performance of growth and immune response of tiger shrimp after cultured for 3 months in a concrete pond

\begin{tabular}{|c|c|c|}
\hline \multirow{2}{*}{$\begin{array}{c}\text { Peubah } \\
\text { Variables }\end{array}$} & \multicolumn{2}{|c|}{ Pakan uji (Test diet) } \\
\hline & PS & PK \\
\hline $\begin{array}{l}\text { Bobot akhir rata-rata } \\
\text { Average final body weight }(\mathrm{g})\end{array}$ & $\begin{array}{l}\text { Betina (Female): } 119.1 \pm 13.8 \\
\text { Jantan (Male): } 90.7 \pm 8.7\end{array}$ & $\begin{array}{l}\text { Betina (Female): } 113.9 \pm 12.4 \\
\quad J a n t a n \text { (Male): } 84.9 \pm 8.8\end{array}$ \\
\hline $\begin{array}{l}\text { Laju pertumbuhan spesifik (\%hari) } \\
\text { Specific growth rate (\%day) }\end{array}$ & $\begin{array}{l}\text { Betina (Female): } 1.12 \\
\text { Jantan (Male): } 0.88\end{array}$ & $\begin{array}{l}\text { Betina (Female): } 1.09 \\
\text { Jantan (Male): } 0.77\end{array}$ \\
\hline $\begin{array}{l}\text { Sintasan } \\
\text { Survival rate }(\%)\end{array}$ & 98.0 & 96.0 \\
\hline \multicolumn{3}{|l|}{ Jumlah hemosit total (x $\left.10^{7} \mathrm{sel} / \mathrm{mL}\right)$} \\
\hline Bulan ke-2 (The $2^{\text {nd }}$ months) & $4.93 \pm 0.52$ & $3.67 \pm 0.47$ \\
\hline Bulan ke-3 (The $3^{\text {rd }}$ months) & $0.84 \pm 0.76$ & $0.56 \pm 0.41$ \\
\hline \multicolumn{3}{|l|}{$\begin{array}{l}\text { Aktivitas phenoloksidase } \\
\text { Phenoloxidase activity (unit) }\end{array}$} \\
\hline Bulan ke-2 (The $2^{\text {nd }}$ months) & $0.11 \pm 0.01$ & $0.10 \pm 0.02$ \\
\hline Bulan ke-3 (The $3^{\text {rd }}$ months) & $0.11 \pm 0.08$ & $0.11 \pm 0.03$ \\
\hline
\end{tabular}


metabolisme normal dan fungsi fisiologis dalam tubuh (Sen et al., 2006). Selanjutnya, Gao et al. (2012) melaporkan adanya peningkatan performansi pertumbuhan yang nyata pada ikan red sea bream yang diberi pakan dengan suplementasi vitamin $\mathrm{E}$ dibandingkan yang tidak diberi vitamin E. Penambahan vitamin $\mathrm{E}$ dalam pakan juga meningkatkan efisiensi pakan karena vitamin E berperan dalam peningkatan aktivitas enzim pencernaan protease dan lipase (He et al., 2017).

Setelah tiga bulan pemeliharaan di tambak beton, sintasan udang windu yang diberi pakan uji dengan penambahan vitamin $C$ dan vitamin E relatif lebih tinggi $(98,0 \%)$ dibandingkan sintasan udang yang diberi pakan uji tanpa penambahan vitamin C dan vitamin $\mathrm{E}(96,0 \%$. Demikian juga kandungan total hemosit dalam haemolimp rata-rata cenderung lebih tinggi pada udang yang diberi pakan uji dengan penambahan vitamin $\mathrm{C}$ dan vitamin $\mathrm{E}$ dibandingkan pada udang yang diberi pakan uji tanpa penambahan vitamin $C$ dan vitamin $\mathrm{E}$, baik pada saat setelah dua bulan pemeliharaan maupun pada saat setelah tiga bulan pemeliharaan di tambak. Pada saat setelah dua bulan pemeliharaan di tambak, rata-rata nilai aktivitas phenoloksidase dalam haemolimp juga cenderung lebih tinggi pada udang yang diberi pakan uji dengan penambahan vitamin $\mathrm{C}$ dan vitamin $\mathrm{E}$ dibandingkan pada udang yang diberi pakan uji tanpa penambahan vitamin $\mathrm{C}$ dan vitamin $\mathrm{E}$. Pada saat setelah tiga bulan pemeliharaan di tambak, nilai aktivitas phenoloksidase dalam haemolimp tampak berdinamika naik dan rata-rata cenderung lebih rendah pada udang yang diberi pakan uji dengan penambahan vitamin $\mathrm{C}$ dan vitamin $\mathrm{E}$ dibandingkan pada udang yang diberi pakan uji tanpa penambahan vitamin $C$ dan vitamin E. Nilai total hemosit dan aktivitas phenoloksidase yang didapatkan pada penelitian ini lebih tinggi daripada yang didapatkan oleh Tenriulo et al. (2014) pada udang windu transveksi yang diuji tantang dengan Vibrio harveyi yaitu total hemosit 1,18-1,94 (x 107 sel/mL) dan aktivitas phenoloksidase 0,03-0,071 unit. Total hemosit dalam hamolimp berperan membantu inang untuk bereaksi melawan bahan asing dan berbagai respons terhadap infeksi, sehingga total hemosit udang yang rendah rentan terhadap patogen sebaliknya total hemosit yang tinggi dapat meningkatkan status kesehatan organsime karena berpeluang terbentuknya sel-sel fagositik yang sangat berperan dalam mengendalikan serangan mikroorganisme (Johansson et al., 2002). Sementara phenoloksidase merupakan salah satu bentuk pertahanan tubuh humoral krustase (Fagatao et al., 2011). Menurut Braak (2002), kinerja sistem pertahanan tubuh terpusat pada sistem proPO. Enzim proPO dikonversi menjadi enzim fenoloksidase (PO) dengan bantuan enzim yang mengaktifkan profenoloksidase. Enzim PO mengkatalisis oksidasi fenol menjadi kuinon, yang selanjutnya akan menyebabkan terjadinya melanisasi ditandai dengan pembentukan warna bercak gelap di bawah kulit. Enzim ini akan merangsang aktifnya reaksi biologis seperti fagositosis, enkapsulasi, dan nodulasi sebagai pertahanan inang (Rodriquez \& Le Moullac, 2000). Secara umum, sintasan udang windu yang didapatkan pada akhir pemeliharaan di tambak tergolong tinggi. Hal ini ditunjang oleh pakan dan kualitas air yang cukup mendukung bagi sintasan dan pertumbuhan udang windu.

\section{Performansi Reproduksi Udang Windu di Bak Pematangan}

Performansi reproduksi udang windu selama di tambak secara visual belum tampak, yaitu belum mengalami perkembangan kematangan gonad dan belum ditemukan adanya udang betina yang telah mengalami perkawinan secara alami di tambak. Sementara performansi reproduksi udang windu yang tidak diinseminasi selama pemeliharaan di bak pematangan disajikan pada Tabel 3. Pada Tabel 3 tersebut terlihat bahwa jumlah sel sperma dalam setiap kantong spermatofor pada induk udang jantan yang diberi pakan uji dengan penambahan vitamin $\mathrm{C}$ dan vitamin E rata-rata sebanyak $38,96 \times 10^{6}$ sel; cenderung lebih tinggi daripada jumlah sel sperma pada induk udang jantan yang diberi pakan uji tanpa penambahan vitamin C dan vitamin E rata-rata sebanyak 37,72 x $10^{6} \mathrm{sel}$. Vitamin E berperan dalam penguatan, peningkatan dan perkembangan organ reproduksi, mencegah degenerasi spematogenium, serta meningkatkan sintasan spermatid (Cheah \& Yang, 2011). Vitamin E merupakan salah satu molekul antioksidan yang paling penting dalam mempertahankan stres oksidatif dan mencegah produksi lemak peroksida yang bersifat radikal bebas, karena radikal bebas ini dapat menyebabkan infertilitas, morfologi sperma yang tidak normal, serta jumlah sperma yang rendah. Demikian juga vitamin C berperan penting dalam organ reproduksi, dan asupan vitamin $C$ berhubungan erat dengan jumlah dan motilitas sperma, serta mencegah sperma dari kerusakan oksidatif DNA (Begum et al., 2009). Jumlah sel sperma induk udang jantan yang didapatkan pada penelitian ini lebih rendah dibandingkan dengan yang didapatkan oleh Laining et al. (2014) yaitu sebanyak $63,8-91,6 \times 10^{6}$ sel dari induk udang jantan yang diberi pakan mengandung tepung cacing laut.

Dalam mempercepat pematangan induk udang di bak beton yang tidak diinseminasi, maka pada induk betina dilakukan ablasi mata. Selama pemeliharaan tersebut, didapatkan induk betina yang berkembang gonadnya hingga tingkat III-IV sebanyak 16 ekor pada 
Tabel 3. Performansi reproduksi udang windu yang tidak diinseminasi selama pemeliharaan di bak pematangan

Table 3. Reproductive performance of not inseminated tiger shrimp during rearing in the maturation tank

\begin{tabular}{lcc}
\multicolumn{1}{c}{ Peubah } & \multicolumn{2}{c}{ Pakan uji (Test diet) } \\
\cline { 2 - 3 } & PS & PK \\
\hline Jumlah sperma/spermatofor $\left(\times 10^{6}\right.$ sel) & $38.96 \pm 30.59(n=10)$ & $37.72 \pm 27.61(n=9)$ \\
Number of sperm/spermatophore $\left(\times 10^{6}\right.$ cell) & & \\
TKG induk betina (akhir) & III-IV $(n=16)$ & III-IV $(n=10)$ \\
Female gonad stages (final) & $4.97 \pm 1.36(n=16)$ & $4.47 \pm 1.63(n=10)$ \\
GSI (\% & $3.15 \pm 0.50(n=16)$ & $3.07 \pm 0.48(n=10)$ \\
HSI (\% &
\end{tabular}

udang yang diberi pakan uji dengan penambahan vitamin C dan vitamin E, lebih banyak dibandingkan pada induk udang yang diberi pakan uji tanpa penambahan vitamin $\mathrm{C}$ dan vitamin $\mathrm{E}$ yaitu 10 ekor. Nilai gonad somatic index (GSI) dan hepato somatic index (HIS) pada induk udang betina yang diberi pakan uji dengan penambahan vitamin $\mathrm{C}$ dan vitamin $\mathrm{E}$ juga cenderung lebih tinggi berturut-turut sebesar 4,97\% dan 3,15\% dibandingkaan pada induk udang windu yang diberi pakan uji tanpa penambahan vitamin $\mathrm{C}$ dan vitamin $\mathrm{E}$ yaitu berturut-turut $4,47 \%$ dan $3,07 \%$ Hal ini menunjukkan bahwa aktivitas metabolisme ke arah perkembangan gonad udang juga sedikit meningkat oleh adanya penambahan vitamin $\mathrm{C}$ dan $\mathrm{E}$. Menurut Cavalli et al. (2003) vitamin C dan E sangat berperan dalam proses vitellogenesis, dan vitellogenin pada udang sebagian besar diproduksi pada bagian hepatopankreas dan ovari (Quackenbush, 1989).

Tabel 4. Rata-rata performansi reproduksi udang windu betina yang diinseminasi selama pemeliharaan di bak pematangan

Table 4. The average of reproductive performance of inseminated tiger shrimp during rearing in the maturation tank

\begin{tabular}{|c|c|c|}
\hline \multirow{2}{*}{$\begin{array}{l}\text { Peubah } \\
\text { Variables }\end{array}$} & \multicolumn{2}{|c|}{ Pakan uji (Test diet) } \\
\hline & PS & PK \\
\hline $\begin{array}{l}\text { Jumah induk betina per bak (ekor) } \\
\text { Number of female per tank (ind.) }\end{array}$ & 7 & 7 \\
\hline $\begin{array}{l}\text { Jumlah induk betina diinseminasi } \\
\text { Number of female inseminated }(\%)\end{array}$ & $78.5 \pm 10.0^{a}$ & $85.7 \pm 20.2^{\mathrm{a}}$ \\
\hline $\begin{array}{l}\text { Jumlah induk memijah } \\
\text { Number of female spawned }(\%)\end{array}$ & $61.7 \pm 30.6^{a}$ & $75.7 \pm 6.1^{\mathrm{a}}$ \\
\hline $\begin{array}{l}\text { Jumlah fekunditas telur per pemijahan (butir) } \\
\text { Egg fecundity per spawned (egg) }\end{array}$ & $131,308 \pm 5,032^{\mathrm{a}}$ & $88,621 \pm 58,814^{a}$ \\
\hline $\begin{array}{l}\text { Produksi telur per bak (butir) } \\
\text { Total egg production pertank (egg) }\end{array}$ & $464,916 \pm 209,417^{a}$ & $377,999 \pm 142,833^{a}$ \\
\hline $\begin{array}{l}\text { Diameter telur } \\
\text { Egg diameters }(\mu \mathrm{m})\end{array}$ & $280.3 \pm 2.4^{\mathrm{a}}$ & $276.1 \pm 3.7^{\mathrm{a}}$ \\
\hline $\begin{array}{l}\text { Kisaran daya tetas telur } \\
\text { Hatching rate ranges }(\%)\end{array}$ & $0-38.0^{\mathrm{a}}$ & $0-21.0^{\mathrm{a}}$ \\
\hline $\begin{array}{l}\text { Kisaran jumlah produksi nauplii per bak (ekor) } \\
\text { Nauplii production ranges per tank (ind.) }\end{array}$ & $0-48,100^{\mathrm{a}}$ & $0-8,500^{\mathrm{a}}$ \\
\hline
\end{tabular}

Keterangan: Nilai dalam baris yang sama diikuti oleh superscript yang sama menunjukkan tidak berbeda nyata $(P>0,05)$ Note: $\quad$ Means in the same row followed by the same superscript are not significantly different $(P>0.05))$ 
Hasil pengamatan performansi reproduksi induk udang windu yang diinseminasi disajikan pada Tabel 4. Meskipun setiap bak berisi tujuh ekor induk betina, namun tidak semua induk betina tersebut mengalami ganti kulit selama pengamatan berlangsung, dan hanya induk betina yang mengalami ganti kulit (kulit lembek) yang dapat diinseminasi. Hal ini menyebabkan hanya 78,5\%induk betina yang diinseminasi pada perlakuan PS dan $85,7 \%$ induk betina yang diinsemiasi pada perlakuan PK, dan nilai pada kedua perlakuan tersebut tidak berbeda nyata $(P>0,05)$. Demikian juga beberapa variabel kinerja reproduksi lainnya seperti jumlah induk memijah, fekunditas telur, jumlah produksi telur, diameter telur, daya tetas telur, dan jumlah produksi nauplii, semuanya tidak menunjukkan adanya perbedaan yang nyata $(P>0,05)$ di antara kedua perlakuan tersebut. Namun demikian, berdasarkan data tersebut tampak bahwa dari sekian banyak variabel yang diamati, umumnya memberikan indikasi bahwa performansi reproduksi udang windu yang diberi pakan dengan penambahan vitamin $\mathrm{C}$ dan vitamin $\mathrm{E}$ dalam pakan uji cenderung lebih tinggi dibandingkan pada udang yang diberi pakan tanpa penambahan vitamin C dan vitamin E. Vitamin C merupakan salah satu komponen nutrisi esensial yang diperlukan dalam pakan dan berperan penting dalam peningkatan frekuensi pemijahan, kualitas telur, dan sperma udang penaeid (Cahu et al., 1995; Wouters et al., 1999; Wouters et al., 2001). Vitamin E juga berperan meningkatkan kualitas telur hewan akuatik seperti dilaporkan pada ikan gilthead sea bream (Izquierdo et al., 2001) dan rainbow trout (Bilguven, 2014). Usman et al. (2019) juga melaporkan bahwa udang windu fase prematurasi yang diberi pakan komersial yang dimodifikasi dengan suplementasi vitamin $\mathrm{C}$ dan $\mathrm{E}$ memiliki kandungan asam lemak arachidonic (ARA), docosahexaenoic (DHA), dan eicosapentaenoic (EPA) pada hepatopankreas dan oosit yang lebih tinggi (indikasi kualitas induk yang lebih baik) dibandingkan pada hepatopankreas dan oosit udang windu fase prematurasi yang diberi pakan tanpa suplementasi vitamin C dan E. Vitamin C dan vitamin E secara sinergis mampu mencegah low density lipoprotein (LDL) teroksidasi, berfungsi sebagai antioksidan, utamanya pada membrane sel atau tepatnya pada lipid membran sel, sirkulasi LDL, hati, dan jaringan adrenalin (Combs, 1992).

Telur-telur yang diproduksi oleh induk udang windu tambak ini umumnya tidak fertil baik dari induk yang diberi pakan uji dengan penambahan vitamin $C$ dan vitamin $\mathrm{E}$ maupun dari induk yang diberi pakan uji tanpa penambahan vitamin C dan vitamin E. Lante \& Laining (2016) melaporkan bahwa induk udang windu tambak sangat sulit kawin secara alami, sehingga diperlukan inseminasi buatan. Pada penelitian ini, beberapa induk udang windu tambak tersebut telah diinseminasi buatan, namun telur yang dihasilkan umumnya masih belum fertil. Hal ini menunjukkan bahwa metode inseminasi buatan yang diterapkan masih perlu diperbaiki. Beberapa hal yang masih perlu perbaikan dalam metode inseminasi ini antara lain: (i) memastikan posisi peletakan spermatofora dalam telicum induk betina yang tepat, (ii) adanya jaminan spermatofara tidak terlepas dari telicum sebelum terjadi pembuahan, (iii) induk betina tidak mengalami stres yang berlebihan selama proses inseminasi, dan lain-lain. Rendahnya tingkat fertilitas dan daya tetas telur yang dihasilkan dari pemihajan induk udang windu hasil budidaya di tambak ini, menyebabkan produksi nauplii dari kedua perlakuan pakan uji masih rendah.

\section{KESIMPULAN}

Udang windu fase prematurasi yang diberi pakan dengan penambahan vitamin C (mengandung 406,1 $\mathrm{mg} / \mathrm{kg}$ pakan) dan vitamin E (mengandung $286,3 \mathrm{mg} /$ kg pakan) memiliki performansi pertumbuhan dan reproduksi, serta respons imun yang relatif lebih tinggi dibandingkan udang yang diberi pakan uji tanpa penambahan vitamin $C$ dan vitamin E. Penambahan vitamin $C$ dan $E$ dalam pakan cenderung meningkatkan performansi pertumbuhan, dan reproduksi udang windu.

\section{DAFTAR ACUAN}

Alava, V.R., Kanazawa, A., Teshima, S., \& Koshio, S. (1993). Effect of dietary phospholipid and n-3 highly unsaturated fatty acids on ovarian development of Kuruma prawn. Nippon Suisan Gakkaishii, 59, 345-351.

AOAC International. (1999). Official methods of analysis. $16^{\text {th }}$ ed. USA: Gaithersberg, Maryland. Association of Official Analytical Chemists International, $1141 \mathrm{pp}$.

Begum, H., Moniruddin, A.B.M., \& Nahar, K. (2009). Environmental and nutrition aspect in male infertility. Journal of M edicine, 10, 16-19.

Bilguven, M. (2014). The effects of vitamin $A$ and $E$ supplementation into the female broodstock diets of rainbow trout (Oncorhyinchus mykiss, W.) on the fecundity and egg quality parameters. Journal of Animal and Veterinary Advances, 13(19), 11201125.

Binh, T.N., Koshio, S., Sakiyama, K., Harakawa, S., Gao, J., Mamauag, R.E., Ishikawa, M., \& Yokoyama, S. (2012). Effects of dietary vitamin $C$ and $E$ and their interaction on reproductive performance, larval quality and tissue vitamin contents in kuruma 
shrimp, Marsupenaeus japonicus Bate. Aquaculture, 334-337, 73-81.

Braak, K.van den. (2002). Haemocytic defence in black tiger shrimp (Penaeus monodon). Ph.D. Thesis. Nedherlands: Wageningen University, 159 pp.

Cahu, C.L., Cuzan, G., \& Quazuguel, P. (1995). Effect of highly unsaturated fatty acid, al pha-tocopherol and ascorbic acid in broodstock diet on egg composition and development of Penaeus indicus. Comparative Biochemistry Physiology, 112(3-4), 417-424.

Cavalli, R.O., Batista, F.M.M., lavens, P., Sorgeloos, P., Nelis, H.J., \& De Leenheer, A.P. (2003). Effect of dietary supplementation of vitamin $C$ and $E$ on maternal performance and larval quality of the prawn Macrobrachium rosenbergii. Aquaculture, 227(1-4), 131-146.

Celada, J.D., Fuertes, J.B., Carral, J.M., Saez-Royuela, M., Gonzalez, A., \& Gonzalez-Rodriquez, A. (2013). Effect of vitamin $C$ inclusion in practical diets on survival and growth of juvenile crayfish (Pacifastacus leniusculus Dana, Astacidae) from the onset of exogenous feeding. Aquaculture Nutrition, 19, 110-116.

Cheah, Y. \& Yang, W. (2011). Function of essential nutrition for high quality spermatogenesis. Advances in Bioscienceand Biotechnology, 2, 182-197.

Combs, G.F.Jr. (1992). The vitamin: Fundamental aspects in nutrition and health. New York: Academic Press, $525 \mathrm{pp}$.

Conklin, D.E. (1997). Vitamin. In D'Abramo, L.R., Conklin, D.E., \& Akiyama, D.M. (Eds.). Crustacean Nutrition - Advances in Word Aquaculture VI. USA: Los Angeles, Baton Rouge. World Aquacuture Society, p. 123-149.

Diwan, A.D., Joseph, S., \& Ayyappan, S. (2009). Physiology of reproduction, breeding and culture of tiger shrimp Penaeus monodon (Fabricius). Delhi. India: Narendera Publishing House, 292 pp.

Fagatao, F.F., Kondo, H., Aoki, T., \& Higono, I. (2011). Prophenoloxidase has a role in innate immunity in penaeid shrimp. In Bondad-Reantoso, M.G., Jones, J.B., Corsin, F., \& Aok. T. (Eds.). Diseases in Asia Aquaculture VII. Selangor, Malaysia: Fish Health Section, Asian Fisheries Society, p. 171-176.

Gao, J., Koshio, S., Ishikawa, M., Yokoyama, S., Maung, R.E.P., \& Han, Y. (2012). Effect of dietary oxidized fish oil with vitamin $E$ supplementation on growth performance and reduction of lipid peroxidation in tissues and blood of red sea bream, Pagrus major. Aquaculture, 356-357, 73-79.
Guillaume, J., Kaushik, S., Bergot, P., \& Metailler, R. (1999). Nutrition and feeding of fish and crustaceans. UK: INRA, IFRAMER, Springer, 408 pp.

Halver, J.E. (2002). The vitamins. In Halver, J.E. \& Hardy, R.W. (Eds.). Fish Nutrition. New York: Academic Press, p. 453-504.

He, M., Wan, K., Liang, X., Fang, J., Geng, Y., Chen, Z., Pu, H., Hu, Y., Li, X., \& Liu, L. (2017). Effect of dietary vitamin $\mathrm{E}$ on growth performance as well as intestinal structure and function of channel catfish (Ictalurus punctatus, Rafinesque, 1818). Experimental and Therapeutic Medicine, 14, 57035710.

Hoa, N.D. (2009). Domestication of black tiger shrimp (Penaeus monodon) in recirculation systems in Vietnam. Ph.D. Thesis. Belgium: GhentUniversity.

Hsu, T.S. \& Shiau, S.Y. (1997). Comparison of L-ascorbyl-2-polyphosphate with L-ascorbyl-2-sulfate in meeting vitamin $C$ requirement of juvenile grass shrimp, Penaeus monodon. Fisheries Science, 63(6), 958-962.

Izquierdo, M.S., Fernandes-Palacios, H., \& Tacon, A.G.J. (2001). Effect of broodstock nutrition on reproduction performance of fish. Aquaculture, 197, 25-42.

Johansson, M.W., Keyser, P., Sritunyalucksana, K., \& Soderhall, K. (2002). Crustacean haemosytes and haemotopoiensis. Aquaculture, 191, 45-92.

Laining, A., Usman, \& Trismawanti, I. (2016a). Dietary carotenoid in prematuration diet enhanced gonadal maturation and total carotenoid in several tissues of pond reared black tiger shrimp (Penaeus monodon). Indonesia: Surabaya, 26-29 April 2016. Book of Abstract of Asian Pacific Aquaculture 2016.

Laining, A., Rachmansyah, Usman, Palinggi, N.N., Kamaruddin, Lante, S., Trismawanti I., Santiadjinaata, W., Tamsil, Rosni, Umar, \& Ramadhan. (2016b). Formulasi pakan prematurasi udang windu. Laporan Tahunan. Balai Renelitian dan Pengembangan Budidaya Air Payau, Maros, $33 \mathrm{hlm}$.

Laining, A., Usman, \& Rachman Syah. (2014). The use seaworm meal in maturation diet as partial substitution of fresh diet for pond reared tiger shrimp broodstoock. IndonesianAquaculture Jounal, 9(2), 123-132.

Lante, S. \& Laining, A. (2016). Aplikasi inseminasi buatan pada udang windu, Penaeus monodon alam menggunakan sumber dan jumlah spermatofora yang berbeda. Jurnal Riset Akuakultur, 11(3), 271-280. 
Lee, M.H. \& Shiau, S.Y. (2002). Dietary vitamin C and its derivatives affect immune responses in grass shrimp, Penaeus monodon. Fish Shellfish Immunol., 12, 119-129.

National Research Council (NRC). (2011). Nutrient requirements of fish and shrimp Washington, D.C.: National Academy Press, 392 pp.

Paibulkichakul, C., Piyatiratitivorakul, S., Sorgeloos, P., \& Menasveta, P. (2008). Improved maturation of pond-reared, black tiger shrimp (Penaeus monodon) using fish oil and astaxanthin feed supplements. Aquaculture, 282, (1-4), 83-89.

Rodriquez, L. \& Le Moullac, G. (2000). State of the art immunological tools and health control of penaeid shrimp. Aquaculture, 191, 109-119.

Quackenbush, L.S. (1989). Vitellogenesis in the shrimp, Penaeus vannamei in vitro studies of the isolated hepatopancreas and ovary. Comparative Biochemistry and Physiology, 94B, 253-261.

Sen, C.K., Khanna, S., \& Roy, S. (2006). Tocotrienols: Vitamin E beyond tocopherol. Life Scince, 78, 20882098.

Tenriulo, A., Parenrengi, A., \& Tampangallo, B.R. (2014). Respons imum udang windu, Penaeus monodon, yang membawa marker DNA tahan penyakit setelah dipapar bakteri pathogen Vibrio harveyi. Dalam Sugama, K., Kusnendar, E., Rachmansyah, Giri, I N.A., Yuhana, M., Kristanto, A.H., Imron, Radiarta, I N., \& Dewi, R.R.S.P.S. (Eds.). Prosiding Forum Inovasi Teknologi Akuakultur (FITA) 2014. Pusat Penelitian dan Pengembangan Perikanan Budidaya, hlm. 975-983.
Usman, Kamaruddin, Laining, A., \& Trismawanti, I. (2019). Fatty acid profile of hepatopancreas and oocyte of tiger shrimp, Penaeus monodon, fed modified-commercial diet by supplementing vitamin C and E. Aquacultura Indonesiana, 20(1), 15-23.

Waagbo, R. (2010). Review article: Water soluble vitamin in fish ontogeny. Aquaculture Research, 41, 733-744.

Wouters, R., Gomez, L., Lavens, P., \& Calderon, J. (1999). Feeding enriched Artemia biomassa to Penaeus vannamei broodstock its effect on reproductive performance and larval quality. Journal of Shellfish Research, 18(12), 651-656.

Wouters, R., Lavens, P, Nieto, J., \& Sorgeloos, P. (2001). Penaeid shrimp broodstock nutrition: an updated review on research and development. Aquaculture, 202, 1-21.

Xavier, B., Jain, K.K., Pal, A.K., Sahu, N.P., Maheswarudu, G., Gal, D., \& Kumar, S. (2016). Mixed feeding schedule of low and high protein in the diet of Labeo rohita (Hamilton) fingerlings, effect on growth performance, haemato-immunological and stress responses. Aquaculture, 22, 652-663.

Yano, I., Ruchimat, T., Sutarmat, T., Tridjoko, Lante, S., Hutapea, J.H., Makinouchi, S., \& Kuma, C. (1996). Effects of vitamin $E$ on maturation and spawning in giant tiger prawn, Penaeus monodon. Suisanzoshoku, 44(4), 497-502. 